\title{
Lessons from the "Periphery": Countering Anglo-Geographic Hegemony over geographies of sexuality and gender*
}

\author{
Michal Pitoňák \\ Queer Geography (NGO). Prague, Czechia \\ michal.pitonak@queergeography.cz
}

Received: November 2018

Accepted: April 2019

Published: June 2019

\begin{abstract}
This article has three aims. First, I discuss the existing inequalities within the systems of knowledge production dominated by "Anglo-American" academia and critically examine the "East-West" binary to show that sexuality and gender/feminist scholars in geography should learn from their deconstructive skills to overcome hegemonies erected by these binaries both in academia and the related geopolitical landscapes. Second, I critically discuss the concept of "Central and Eastern Europe" (CEE) which I do not intend to stabilize, and hold up a mirror to the various hegemonic misunderstandings that take the form of "homogenization", "dehistoricization", "isolation" or by ascribing "backwardness", by which they effectively erase or overlook knowledges and contributions of "non-AngloAmerican" scholars often left "beyond translation." Last, I concentrate on the discussion of the development of geographies of sexualities and gender/feminist thought in CEE geography and illustrate the challenges that scholars from different institutional and national contexts must still face. By this article, I attempt to stand for our/their recognition.
\end{abstract}

Keywords: geographies of sexualities; Anglo-American hegemony; Central and Eastern Europe; Gender; Feminist geographies; Queer; Knowledge production

* I would like to thank Maria Rodó de Zárate for offering me a chance to submit my manuscript to this journal and to Juan Antonio Módenes Cabrerizo who helped me with the process of revising my manuscript. I also want to thank both anonymous reviewers and my friend Jennifer Fluri who gave me valuable feedback to my first draft. This paper is a result of an independent research conducted at Queer Geography which is a non-governmental organization set in Prague (Czechia) that aims to support researchers interested in the field of geographies of sexualities and related disciplines. 
Resum. Lliçons des de la "periferia»: contrarestar l'hegemonia anglogeogràfica de les geografies de la sexualitat $i$ de gènere

Aquest article té tres objectius. En primer lloc, es discuteixen les desigualtats existents en els sistemes de producció del coneixement dominats per l'acadèmia «angloamericana» $\mathrm{i}$ s'examina críticament el binarisme Est-Oest per mostrar que la sexualitat i els/les acadèmics/ ques en geografia i gènere/feminista haurien d'aprendre de les seves habilitats desconstructives per superar les hegemonies que sorgeixen d'aquestes concepcions binàries, tant en l'acadèmia com en espais geopolítics relacionats. En segon lloc, es discuteix críticament el concepte d'Europa Central i Oriental (CEE) — que no intento estabilitzar - i s'examinen els diferents tipus de malentesos hegemònics, tals com "homogeneïtzació», "deshistorització», «aillament» o «endarreriment», pels quals s'eliminen o es passen per alt coneixements i contribucions d'acadèmics/ques "no angloamericans/es», de manera que queden «fora de traducció». Finalment, l'article se centra en el debat sobre el desenvolupament de les geografies de les sexualitats i de gènere/feministes en la geografia dels països de la CEE i s'il.lustren els reptes que encara tenen els/les acadèmics/ques de diferents contextos institucionals $\mathrm{i}$ nacionals. Aquest article pretén mostrar el nostre/el seu reconeixement.

Paraules clau: geografies de les sexualitats; hegemonia angloamericana; Europa Central i Oriental; gènere; geografies feministes; queer; producció de coneixement

Resumen. Lecciones desde la "periferia»: contrarrestar la hegemonía anglogeográfica de las geografias de la sexualidad y de género

Este artículo tiene tres objetivos. En primer lugar, se discuten las desigualdades existentes en los sistemas de producción del conocimiento dominados por la academia «angloamericana» y se examina críticamente el binarismo Este-Oeste para mostrar que la sexualidad y los/ las académicos/as en geografía de género/feminista deberían aprender de sus habilidades deconstructivas para superar las hegemonías que surgen de estas concepciones binarias, tanto en la academia como en espacios geopolíticos relacionados. En segundo lugar, se discute críticamente el concepto de Europa Central y Oriental (CEE) — que no intento estabilizar-y se examinan los distintos tipos de malentendidos hegemónicos, tales como «homogeneización», «deshistorización», «aislamiento» o «atraso», por los cuales se eliminan o se pasan por alto conocimientos y contribuciones de académicos/as «no angloamericanos/ as», de modo que quedan "fuera de traducción». Finalmente, el artículo se centra en el debate sobre el desarrollo de las geografías de las sexualidades y de género/feministas en la geografía de los países de la CEE y se ilustran los desafíos en los que todavía se encuentran los/las académicos/as de distintos contextos institucionales y nacionales. Este artículo pretende mostrar nuestro/su reconocimiento.

Palabras clave: geografías de las sexualidades; hegemonía angloamericana; Europa Central y Oriental; género; geografías feministas; queer; producción de conocimiento

\section{Resumé. Leçons de la "périphérie» : contrecarrer l'hégémonie anglo-géographique des géographies de la sexualité et du genre}

Cet article se donne trois objectifs. Tout d'abord, les inégalités existantes dans les systèmes de production de connaissances dominés par l'académie «anglo-américaine» sont discutées et le binarisme «Est-Ouest» est examiné de manière critique pour montrer que la sexualité et les chercheurs en géographie du genre/féministe devraient apprendre de leurs capacités déconstructives afin de surmonter les hégémonies résultant de ces conceptions binaires, à la fois dans les milieux universitaires et dans les espaces géopolitiques connexes. 
Deuxièmement, le concept «d'Europe Centrale et Orientale» (CEE) - que je ne cherche pas à stabiliser - est discuté de manière critique, et les différents types de malentendus hégémoniques tels que "homogénéisation", «déshistoritisation», «isolement» ou "retard» par lesquels les connaissances et les contributions des érudits "non anglo-américains» sont éliminées ou ignorées, restant ainsi «hors traduction». Finalement, l'article se concentre sur le débat autour du développement des géographies des sexualités et du genre/féministes dans la géographie des pays de l'Europe Centrale et Orientale et illustre les défis auxquels font face les chercheurs de différents contextes institutionnels et nationaux. Cet article vise à montrer notre/leur reconnaissance.

Mots-clés: géographies des sexualités; hégémonie anglo-américaine; Europe Centrale et Orientale; genre; géographies féministes; queer; production de connaissances

\begin{aligned} & \multicolumn{2}{c}{ Summary } \\ & 1. Introduction 4. Conclusion \\ & 2. Hegemonic knowledges Bibliographical references \\ & 3. "Fight" for recognition: feminist and \\ & sexuality thought in "CEE" \end{aligned}

\section{Introduction}

In September 2017 I organized a session called "Central and East European, Baltic and Balkan Geographies of Sexualities: it's time to speak up!" that was part of the IV European Geographies of Sexualities Conference. The number of accepted contributions reached 15 , and this resulted in splitting the meeting into three sessions. Scholars from eight different countries presented their papers and engaged in rich discussions within this unique opportunity to meet in Barcelona. Within this empowering space, I for the first time experienced a space where a session, oriented purely at advancing in non-Anglo-American geographies of sexualities, took place. Although I am convinced that this unique gathering was a success, I am also confident that many have faced barriers, been excluded or encountered other obstacles that disabled them from participating. For me, it was the I European Geographies of Sexualities Conference that took place in Brussels (2011) that allowed me to participate at such an international event for the first time. Since then I have striven to introduce the field of geographies of sexualities into Czech geography. However, these efforts have been far from straightforward. Having to face complicated situations, job insecurity, but also experiencing peer support, finding reason, and international friendships, I became motivated to gain a deeper understanding of the diverse factors that influence scholars, including me, who seek to examine geographies of sexualities and/or feminist/gender geographies, despite the fact that this academic path may render them "dissident" in some regional or scholarly contexts more than in others. In conjunction, I also wanted to contribute to the discussion about what hinders the development of these scholarly fields 
beyond the "Anglo-American" context, and put both internationally-relevant factors, such as hegemonic relations linked to the processes of knowledge production and knowledge recognition as well as local factors, into consideration.

\section{Hegemonic knowledges}

Are you a native English speaker? Do you publish in predominantly English journals? Have you decided to publish in your native or second language? In which languages can you comfortably read? Do you have access to a library with scientific literature in your field of interest? Do you face barriers in being able to participate at scientific conferences? Has your research become accepted by your institution? Is there an institution behind you or are you an independent scholar? Was or is the choice of your methods influenced by the institutional environment? Have you been able to find a job in the field of your expertise? Did you move abroad, or did you stay? These are only a few of many questions which we may employ to understand the influences and potentials of knowledge productions of various scholars in various localities.

While some authors have recognized existing hegemonies in terms of the Anglo-American ${ }^{1}$ dominance in knowledge production (Blažek and Rochovská, 2006; Brown and Browne, 2016) or the Eurocentrism of contemporary social sciences (Kulpa and Silva, 2016), they have been less tangible in naming the concrete barriers and even less often offered tools or courageous visions by which it would be possible to overcome and/or deconstruct them (Kitchin, 2003, 2005; Kulpa and Silva, 2016; Timár, 2007; Timár and Fekete, 2010; Tlostanova, 2014). Despite these repeated calls, the hegemony of this knowledge production has had and continues to have a substantial impact on the shape of (not-only) European discourses in gender/feminist, ${ }^{2}$ sexuality and queer studies.

These hegemonies have erected reductionist understandings which are partially based on uncritical applications of binaries such as "Global North" and "Global South," "East" and "West" that effectively "other(ed)s" those "beyond." These hegemonies have created (new) hierarchies and objectivized distinction between the imaginations of "modern West" and the "homophobic East" and (re)constructed the narratives of "homogeneity," "backwardness," "lack of humanity," and/or perpetual "catching up" with the ideals singled out in/by seemingly homogeneous "West" that often stands for the "Anglophone West" (Ayoub and Paternotte, 2014; Kulpa and Silva, 2016; Navickaite, 2014; Rodó de Zárate, 2016; Stella, 2014; Szulc, 2018; Tlostanova, 2014).

1. Sometimes authors refer to "Western" or "Euro-American" dominance. I use this term similarly as Timár (2007) to substantiate that regardless of the fact I write from a European perspective, we may still recognize various hegemonies and distinctive scholarly traditions that can be juxtaposed with the Anglo-American (e.g., Czech, Hungarian, French, Spanish, German etc.). By applying the term Anglo-American, I by no means intend to erase those being pushed to its own peripheries (e.g., South Africa, New Zealand, etc.).

2. Due to the frequent use of both terms, I will use these terms interchangeably. 
In the context of what authors call, for example, "epistemic hegemonies" we may ask how do geographical location and/or (a lack of) institutional affiliation determine who gets recognized as a "knowledge producer" and who is subdued as "informant and data miner" (Kulpa and Silva, 2016: 142). Similarly, in their critique of Anglophone hegemony, Garcia Ramon et al. (2006) stress that "knowledge from 'other' places is construed as exceptional, divergent and local and, as such, not producing 'theory', only 'case studies"' (ibid, 2006: 3). This is also Tlostanova's point when she criticizes (Western) postcolonial studies as marked by a clear subject/object division, distinguishing between the subject who studies and the object which is studied:

The postsocialist and post-Soviet world has continued to vacillate between the position of the subject and the object in the last two decades. We were supposed to either reform ourselves and become modern and Western subjects in some distant future, to join the refurbished global South when applicable, or to simply vanish. (2014: 162)

Tlostanova's (2014: 160) argument focuses on understandings of modernity and humanism, where power hierarchies are reproduced with some of us branded as "not quite human" as in "not quite European," "not quite Christian," "not quite white," etc.

All these terms represent binary categories related to power relations conveying meaning and highlighting established dominant or hegemonic perspectives. Indeed, feminist and sexuality scholars have been rather successful in deconstructing ${ }^{3}$ sexuality and gender identity-related categories; however, it seems they have so far largely failed to apply these approaches for overcoming the normatively established hegemonies within their modes of knowledge production (Garcia Ramon and Monk, 2007).

Authors concur that one of the obvious sources of these hegemonies emerged from the current "economies of knowledge production" which, in the context of feminist geography and sexuality studies, take the form of financial limitations posing as barriers to access academic texts (Timár, 2007). While many have been shocked by Alexandra Elbakyanova's Sci-Hub project, it still represents the only conduit to academic texts for many who do not know how

3. We have come to an understanding that binary terms, as well as other signifiers, are products of performative use of language (Butler, 1999). This lies at the heart of both social-constructivist and post-structuralist thought. We can no longer say things (e.g., gender) "are", but that they "are being done" (performed, reiterated), and we understand that it is various forms of "amnesias of alternatives" that produce them as convincingly fixed categories (Berger and Luckmann, 1991). As structuralist, post-structuralist and psychoanalytic scholars have pointed out, the evasive nature of meaning regarding these seemingly fixed categories favor conditions in which it is "what something is not" that is more easily conveyed than "what something is," thus giving rise to endless binary categories "defined" by their "mutual exclusivity" with potentially endless space for their deconstruction. According to Sedgwick (1990), we can deconstruct binaries by problematizing them, by adding a third term to the existing binary as well as by re-interpreting them as spectra. 
to overcome paywalls of gate-kept neoliberal, for-profit, academic publishing houses. Kitchin has discussed these barriers from the side of publishing houses before (Kitchin, 2005). Sci-Hub enforces "open-access" and by doing so bypasses paid access to academic journal articles that many cannot access. As I will further discuss, this barrier is specifically difficult to overcome in fields such as geographies of sexualities or feminist/gender geographies that in fact constitute "dissident fields" of inquiry in many regional contexts in which scholars need to "fight for recognition" and resist the mainstream academia that continues to exclude them (Timár and Fekete, 2010).

Scholars have also recognized that the majority of knowledge is produced through Anglophone journals, and this situation also applies to human geography (Garcia Ramon et al., 2006; Kitchin, 2005; Kulpa and Silva, 2016). Most of the high-ranking human geography journals reside in the US and UK; few others are based in Western-European or Scandinavian countries, most of which accept English as the primary language of publication. Authors as well have recognized that this hegemonic position of English is linked to the increasing dominance of a "global knowledge economy" that favors publishing within the environment of mostly Anglo-American publishing houses (Kitchin, 2003, 2005). In this respect, we should be aware that if we do not publish in our native/local languages then we cannot reach required recognition locally and may consequently cut ourselves off from the support of local institutions and academic positions which could sustain both our research and living (Timár and Fekete, 2010). Not everyone masters English, and if so, we should be more cognizant about the ways in which regarding it as an "academic lingua franca" influences the local knowledge production and the global recognition of local knowledges. For example, Garcia Ramon and Monk (2007: 10) remind us that the very "willingness of Anglophone institutions to value publications in languages other than English as they assess their own colleagues is another political step forward."

In a similar vein, scholars also criticized the scarcity of analyzed nonEnglish academic texts by "Western scholars" stressing the overt rarity of non-English references present even in journals with international scopes, such as Gender, Place and Culture (Garcia Ramon et al., 2006; Navickaite, 2014). Stella (2014) also noted that the dominance of English-speaking academia might be linked to limitations in the competences of native-English speaking scholars who may have difficulties in accessing resources and researching in other languages. She, for example, noticed that endemic "Russian sources might not be familiar to the imaginary 'global' English-speaking reader, more au fait with the work of internationally recognized academic work published in English" (Stella, 2014: 2). Timár in this context documented the quite explicit hegemonic relationship between the newly opened post-socialist "East Central Europe" and the "Western scholars" whom hastened to produce knowledge on behalf of local scholars:

Of the 14 books on gender issues in East Central Europe that I found in Hungarian libraries and that were written in English, only one was publis- 
hed in the region... Of the 166 authors of the 12 books published in the UK or the USA, only 75 lived in the post-socialist region, and only one of these books had an editor from outside of the Anglo-American sphere. (2007: 4)

Consequently, it might be relevant to subject knowledge produced on "behalf of others" to scrutiny as partial and/or incomplete translations may, among other possible outcomes, (re)produce omissions, stereotyping and/or lead to false conclusions. In this regard, Timár and Fekete (2010: 776) argue that "in addition to our partial knowledge, the linguistic diversity of the region already placed restrictions on the process of information-gathering". Various knowledges thus remain "on-site," disregarded, unrecognized or simply locked "beyond translation." On the one hand, these knowledges are "kept" from the gaze of the "global" English-speaking reader, whereas on the other they are also kept from being explored due to various forms of "epistemic hegemonies" and "methodological nationalisms," both leading to the marginalization of feminist and sexualities knowledge within and about "othered" regions.

However, these language hegemonies and barriers do not only influence omissions and lack of sensitivity toward knowledge that is not translated into English, they also contribute to actual incompatibilities and insensitivities when they uncritically introduce foreign vocabularies and/or concepts. Authors have questioned the usefulness of certain English concepts in other linguistic contexts and criticized acceptance of English for "international academic debate," highlighting the fact that even the often uncomplicated "process of translation between languages is highly subjective, political and situated" (Garcia Ramon and Monk, 2007: 8). Rodó de Zárate (2016) has, for example, pointed out that the hegemonic (Anglo-American) understandings of concepts such as "intersectionality," "homonationalism" or "queer" may be counterproductive in other contexts; specifically, she focused on the Catalan context where different epistemic standpoints change the ways in which racism, slavery or other terms are approached. When she criticized the applicability of "queer" outside its Western context, she did not only mention the lack of its comprehensibility in Catalan and Spanish, but also suggested the potential use of this word leading to elitist, academic, connotations. Similarly, Stella (2014) argued that it is necessary for us to be aware of local terminology especially in the sexualidentitarian context, where again it is "queer" that becomes problematic and unfamiliar in Russian, whereas these incompatibilities apply perhaps to all non-Anglo-American contexts.

Indeed, some of these issues have been recognized already. As Brown and Browne (2016: 3) put it, "the word 'queer' itself and the ideas behind it do not translate easily." Far from being uncomplicated, also in Czech, it is sometimes difficult for me to find a balance between the need to critically discuss allochthonous terminology such as "the closet," or "nonheterosexuality" with the need to introduce or employ terminology that 
local scholars, and perhaps more importantly, the public could pick up and use within wider societally and politically relevant discussions. As an effect of this terminological negotiation, one must balance several factors at once. For example, as it is not customary for most people who grew up during the state-socialism to use sexual-identitarian terminology such as gay and lesbian in Czech, and many of the younger generations resist using any sexual-identitarian terms, and at the same time researchers recognize the need to move away from the medicalized "homosexual," I must seek more inclusive and compatible terminology. As a result, I often employ terms such as non-heterosexual (ne-heterosexuálni or neheterosexuální in Czech), encountering that in addition to the need to explain its complicated relation to heteronormativity, unexpected issues also arise when introducing foreign punctuation. Using a hyphenated version ne-heterosexuálni is more limited in Czech as it makes the word look foreign, whereas without it might be more difficult to read.

Aside from terminological issues, some authors have also pointed out the need to carefully approach foreign theories and concepts. Kuhar and Švab (2014), for example, argue that understandings such as "typical urban/rural divide" need to be recognized as inherently "Western experiences." Therefore, they may not be completely applicable to other social and cultural contexts. Similarly, Garcia Ramon et al. substantiate that:

Many non-English languages, our own among them, have only one word and are therefore linguistically unable to act out the sex/gender distinction. It could be seen as a semantic problem that renders us incapable of distinguishing between biological and social factors and criticising biological determinism. (2006: 3)

Awumbila (2007) also discussed the applicability of gender/sex distinction in an African context, showing that gender/sex may sometimes be understood as flexible or comparatively irrelevant in some circumstances. Consequently, we need to be vigilant about seeing local contexts through theoretical lenses developed elsewhere. The insensitive introduction of foreign terminology may spark wider societal antagonisms and ignite emotions that may be more difficult for us to quench than expected. Heated debates about so called "gender ideology" or "political correctness" might all be more easily resolvable if more sensitivity is put into dialogues between languages. Universalism has often been touted as an idealistic form of human rights, but we must be cautious about its potential to erase the particular, the local, and various sociocultural contexts where "difference" needs to be appreciated and not sublimated by the universal (Benhabib, 2011).

In the following three sections I will focus on discussing possible responses to these existing hegemonic knowledges that (re)produce omissions, stereotyping and may lead to false conclusions mainly, but not exclusively, in the context of geographies of gender and sexuality. 


\subsection{Complicating the East-West binary}

Stella et al. (2017: 5) argues that "the narrative of an 'East/West' divide is, in many ways, an oversimplification of a very fluid and complex picture." I write this article from my own situated perspective, in this case located in Czechia. ${ }^{4}$ Therefore I tend to position myself inside of a geopolitical region "imagined and called" "Central Europe," which is a dominant notion in the Czech context (Eberle, 2018). I will aim to utilize this "third" term (West, East, Center) to complicate these often simplistic divides and attempt to contribute to their deconstruction within the field of geographies of sexualities and feminist geographies. I shall admit that there is no one "Central," "East" or "Eastern Europe," but a diverse and rich region defined depending on the author and the region from which s/he comes. Consequently we may call this imagined region Central Europe (CE), Eastern Europe (Navickaité, 2014), Central and Eastern Europe (CEE), East-Central Europe or East and Central Europe (ECE) (Timár and Fekete, 2010) or Post-socialist (Blazek and Šuška, 2017), Eastern or the Soviet bloc (Szulc, 2018), or by any other term such as the New Europe or non-core Europe that may be just "trending" (Balogh, 2017). Still, none of these terms can be attributed a fixed meaning or a territorial shape; all of these concepts are constantly evolving both in time and space (Balogh, 2017). In a way, these have all become "empty signifiers" which are both symbolically ambiguous and highly impactful as powerful signs (e.g., in policymaking) at the same time.

Due to my situatedness, I sometime use the terms "Central Europe" (CE) and "Central and Eastern Europe" (CEE); however, I do not wish to stabilize them but rather complicate them.

The concept of Central Europe at first seems to have a potential in deconstructing the East-West binary (seemingly as a third term). However, a more detailed look unveils that it represents a mere form of geopolitical imagination related to the East-West (hierarchical) binary reflecting the inner hierarchies of this geopolitical power-relationship. Kundera (1984) imagined Central Europe as a culturally homogenous region artificially and temporarily divided by the Iron Curtain. According to Eberle (2018), Kundera has culturally fueled the geopolitical imagination of wishful "reintegration with the West" that was once a reality (the idea of a "kidnapped West"). The idea of Central Europe has also been used to delimit parts of Europe against Russia or the former Soviet Union and has indeed fueled various hierarchical orders, thus creating various degrees of "Easterness" (Tlostanova, 2014). In this way, Czechs have always considered themselves as being "almostwestern" (Eberle, 2018). Central Europe was also utilized in order to "reintegrate" several countries with "the Europe proper" after it was othered as an "improper Europe" during the Cold War (Balogh, 2017). According to Tlostanova:

4. The short geographical name for the Czech Republic. 
[T] he postsocialist countries of Eastern and/or Central Europe have always remained second-class European or in more recent terms, New Europeans, or non-core Europeans. So in their case, the struggle is, first of all, for claiming their right to be considered European with no negative pejorative prefixes and adjectives and, figuratively speaking, to finally be let into the living room of Europe instead of always being kept in the entrance hall as a poor distant relative. (2014: 164)

Tlostanova (2014: 165) further criticized that many scholars still retain a highly generalized image of socialism and totalitarian communism and that they seldom think about the actual nuances that exist within this diverse region

\subsection{Complicating the "homogeneity of the East"}

Neither "East," "West" nor "Centre" has in fact ever been homogenous, and this also applies to their variously imagined subregions, which also "travel" in time and space relative to their imagined geopolitical positions (Kulpa, 2014; Navickaité, 2014). Yet, as Timár and Fekete (2010) observed, feminist and sexuality scholars still treat "Eastern" Europe rather uniformly and approach it uncritically under one umbrella term, most frequently by "post-socialism" or the "East" and by doing so contribute to their inaccurate representations. One of the typical consequences of employing this terminology is the illusion of its homogeneity (Navickaite, 2014; Szulc, 2018; Tlostanova, 2014).

In her discussion on intersections between "the postcolonial" and "the post-socialist," Tlostanova stresses that the tag "post-socialist" is:

$[U]$ nable to successfully glue together the multiplicity of countries, people, cultures, religions, and sensibilities that came under Soviet auspices for several decades in the twentieth century and then dispersed again, joining remaining power vectors of various kinds. (2014: 161)

Here Tlostanova unravels the most crucial factors: the relativity of historical time and the spatiotemporal inertia of power. As geographers, we tend to complicate space and conceptualize its relations to power, yet we should not leave the time out of the equation as both have inertia and "power vectors" as Tlostanova mentioned. These indeed do not exist in a spatial vacuum or some state devoid of time continuities of various points of origin both in time and space. An obvious example of this may be Czechoslovakia, which was part of the Austrian-Hungary empire until 1918, then functioned as a democratic country from 1918 to 1948 (although divided during the Second World War due to the influence of Nazism, when a sizable portion of its territories were annexed by the Third Reich and Slovakia became a fascist state from 19391945) and then became a socialist country from 1948 to 1989, that divorced into Czechia and Slovakia in 1993. Therefore, it would be impossible to simply put Czechia or Czechoslovakia on a map without complicating its history or studying the "power vectors of various kinds" that in fact continue to affect 
local developments, we may thus perhaps conceptualize and study these as some sort of spatiotemporal persistences. Similarly, former Yugoslavia could not be easily attributed to the "East" as Tito's Communist Party of the 1940s decided to break off from Stalin's regime, and the country has geopolitically positioned itself somewhere between East and West and this lasted until Yugoslavia's dissolution in the early 1990s (Kuhar and Švab, 2014).

Tlostanova, in this context, stresses that it is not possible to employ postsocialism as an umbrella term, whereas:

[It] is high time to work out a more complex, theoretically intersecting and properly differentiated approach for the interpretation of post-socialist realities and subjectivities, to avoid studying them as an object from some presumably disembodied position and ghettoing the ex-second world in its intellectual isolation from topical discussions in social theory and criticism. (2014: 168)

In this respect, Szulc (2018) provides a convincing argument in the context of sexual politics within the "Eastern bloc." Not only did he initiate the re-historicizing project of the actually de-historicized accounts of CEE by discussing the development of transnational sexual activism, but he also demonstrated how these movements in different countries ${ }^{5}$ followed different trajectories of development (power vectors), allying themselves with different segments of society or the state such as sexology in Czechoslovakia, the Evangelical Church in East Germany, universities in Slovenia or, alternatively, staying relatively independent in Hungary or Poland (Szulc, 2018: 85).

Therefore, Szulc, like Tlostanova, argues that "first of all, we should acknowledge different trajectories of those provisions throughout the time in particular countries." (2018: 72).

Moreover, authors have also disproved the myth of the impermeability of the Iron Curtain when they pointed out that interactions between the sexual politics in the "East" and activism in the "West" were not only initiated after the end of the Cold War (Navickaite, 2014), but did in fact flourish before (Szulc, 2018). Szulc has recently investigated eight pre-1990s reports published by the Austrian organization Homosexual Initiative Vienna (HOSI), the initiator of the Eastern Europe Information Pool (EEIP) program, which has been aimed at expanding the International Lesbian and Gay Association's (ILGA) reach beyond the "West" since 1981. Szulc (2018: 63) has also begun dismantling the unidirectionality of "progress" where he pointed out that although EEIP aimed "to support the founding of homosexual groups in the region 'according to the Western example," it in turn proved to be complicated due to local variations and resistances to such efforts by the activists themselves. ${ }^{6}$ In his research, Szulc effectively proved that the recent de-historicized depictions of "the Pink Curtain" as having formerly isolated the "East" from the "West"

5. Namely in Czechoslovakia, East Germany, Hungary, Poland and Slovenia.

6. For example, resistance on the part of some Eastern Bloc activists against the "saving gays" narrative (Szulc, 2018: 69). 
are fallacious because the Iron Curtain was in fact "rusted" and, based on his work, he started to re-historicize "the East".

\subsection{Complicating the "backwardness of the East"}

Szulc elegantly demonstrated how the first EEIP report essentialized not only communist ideology but also various "Eastern bloc societies." He and Stella both stress that there is still a prevailing tendency to represent national societies encapsulated within this term as having inferior qualities by using terms such as "Soviet mindset" or "Balkan mentality" (Stella, 2015: 7; Szulc, 2018: 71).

Tlostanova (2014) has explained that these hierarchizations are closely connected to the thesis of modernity, where subjects in "the East" are treated as if they were less humane than their counterparts in "the West". This positioning of human subjects on the maps of humanness makes them unhappy and anxious about losing their standing in the "hierarchy of humanity." This is also what Štulhofer and Sandfort timely observed when they wrote:

[It] seems that in many respects postcommunist Europe is following the sexual trajectory of the West, probably with a delay of some two to three decades. Should we assume that in time sexual landscapes of the postcommunist East will become the mirror image of the West? If so, will it be the triumph of social and economic development, the outcome of the successful modernization of the East? (2005: 16)

Such depictions of backwardness have been repeatedly employed and have been discussed by Navickaite (2014: 169) as "orientalizing" depictions of Western hegemony or superiority that have "created a widespread dissatisfaction and inferiority complex in CEE countries" whereas "this frustration is especially well expressed in the local ultra-nationalist discourse, where anti-Western attitudes in the nationalist rhetoric are often intertwined with homophobia". Timár has also observed these "neo-colonial" relations in her discussion of the development of gender/feminist approaches in East Central European geography. She quoted a paper by Bassnett which I feel compelled to re-quote too:

Today, the terminology of rebirth, of helping, of educating the new democracies is all around us; Poland, Czechoslovakia, Romania, and a whole host of other nations that were blank spaces on the map to most Westerners until very recently are now discussed in the classic language of the colonizer, the parental figure who "discovers" a new land and finds the natives to be childlike creatures who need to be civilized. (Bassnett, 1992: 11 quoted in Timár 2007: 4; emphasis mine)

Accounts of backwardness and the account of "West as an example" were analyzed by Kulpa and Mizielińska (2011: 16-18) who conceptualized them as "Western progress narrative", which effectively narrates that the Western present is the Eastern future to be achieved: "whatever CEE became/is/will 
be, West had become/has already been/will have been". They have attempted to reconceptualize our understanding of this "progress narrative" by de-centering our often homogeneous conceptualization of time. The authors proposed a concept of "temporal disjunction" between "the West" and "CEE" and offered it as an alternative to simplistic accounts of "backwardness" of Eastern Europe's sexual activism. They distinguished a "Western time of sequence" which, according to them, flows in a rather uncomplicated linear fashion, from the "Eastern time of coincidence" which according to the authors may be the reason why post-communist sexual politics are viewed as staying "behind the West" or even "moving backwards."

In her critique, Navickaite (2014: 172) pointed out that this differential conceptualization of time is problematic as it fails to deconstruct the binary between the East and the West and in fact may essentialize their difference and retain an unproblematic view of the "West" as progressive. She criticized the uncomplicated fashion in which authors depicted "West" as coherently progressing from homophile to LGBT to queer.

In fact, there are numerous examples that remind us that the "West" has never been homogenous or progressed linearly. For example, the foundations of the homophile movement built by Magnus Hirschfeld disintegrated due to the rise of Nazism. Britain has recently commemorated the 30 years since the introduction of the infamous Anti-LGBT Section 28 Law introduced by Margaret Thatcher that banned the "promotion of homosexuality" in schools; a law that was repelled by the Labour government in 2003. Section 28 then should be compared to the currently enacted "Anti-gay propaganda" law Russia introduced in 2013. Neither has the global AIDS pandemic represented the same challenges to sexual politics around the world. On the one hand, the moral panic has, for example, deteriorated public opinion about homosexuals in the UK and caused moral panic in the US (McKay, 2014). But it has also contributed towards ending the tabooing of homosexuality in Poland, Hungary, Czechoslovakia, and other CEE countries and was not coded only as a "homosexual disease" but one symptomatic of a general moral and social decay not exclusive to heterosexuals, as several authors have eloquently demonstrated in their work (Kolářová, 2013; Kurimay and Takács, 2017; Szulc, 2018). Similarly, thriving sexual orientation change efforts (SOCE) as "methods" used in an attempt to "change" the sexual orientation of homosexual and bisexual people may be still easily accessible and practiced in the "West" at present, whereas similar techniques may be forbidden elsewhere including regions viewed as part of the "East."

Regardless of these examples, it is impossible to deny that CEE is being represented as less advanced in the context of gender equality and sexual citizenship both by popular media (e.g., accounts of the Rainbow Curtain) and activist organizations. Indeed, there are numerous examples of this, including results from various surveys on stigma, homophobia, bullying, etc. (Pachankis et al., 2016; Pitoňák and Spilková, 2016) or easily verifiable facts such as that no CEE country has thus far opened marriage to same-sex couples. Popular 
"Western" media representations are often keen to publish images of LGBTQ+ migrants leaving Eastern Europe to escape persecution from Chechnya; they also often represent "their countries" as "gay friendly." But we should ask whether they truly are "gay friendly" or whether they have only been successful in marketing themselves as such by recognizing the "pink market" and profiting on "gay tourism" (Binnie, 1995). Authors have also been suspicious of the popular continental rankings, such as the ILGA-Europe Rainbow Europe Map that may only reproduce misconceptions as it might rightfully reflect the legal situation but does not "straightforwardly reflect wider social norms and attitudes" (Stella et al., 2017: 5).

Specifically, we need to be cautious about not drawing oversimplified conclusions about the underlying causation of these situations as they may simultaneously interfere with the efforts of local activists, policymakers, etc. Stella et al. (2017), for example, pointed out that the introduction of samesex union legislation has been more controversial in the CEE region, whereas Browne and Nash (2017: 646) have recently started to complicate the often "untroubled" developmental narratives in "the West" with a new concept of heteroactivism as a means to "engage with the current strategies being deployed in resistance to sexual and gender rights". Therefore, it might be heteroactivism that should be approached more critically and recognized as having been more "advanced" in the CEE region which has mostly been understood as "backward." In this way, the constitutional amendments restricting and defining marriage only as a union between a man and a woman as deliberate interventions aimed to prevent the introduction of same-sex marriage in the CEE need to be viewed as institutional victories of a "more advanced" heteroactivism.

In this vein, other authors have also recognized that the development of "liberal values" should not be left uncomplicated as depictions of "the West" as progressive and liberal may, in fact, conceal other processes that need to be investigated, such as migration of prejudice from the public into the private sphere (Valentine and Harris, 2016).

Narratives of "catching up with the West" therefore need to be revisited as they reproduce a hurtful race for progress, which effectively dehumanizes the "East" as less "advanced", "liberal", "progressive" or "modern"; all of which may fuel imaginaries that permanently freeze CEE and other othered regions as always lagging behind the "West".

In the last section I will focus on complicating our understanding of "why" geographies of sexualities as well as gender/feminist geographies have so far remained rather quiet in the CEE.

\section{3. "Fight" for recognition: feminist and sexuality thought in "CEE"}

Geographies of sexualities (as well as feminist and gender geographies) have become established fields of inquiry over the past three decades, especially within the British and American scholarly traditions (Bell and Valentine, 1995; 
Browne et al., 2007). Brown and Browne (2016: 1) reflect that this loosely defined field of inquiry emerged from "the desire to examine geographical differences in sexualities and their spatial specificities as a key aspect of human geographies". Indeed, before this geographical subdiscipline established itself among the main chapters of geographical thought within Anglo-American human geography it had to overcome several obstacles, and yet I will argue that desire and determination may not be enough for the establishment of this field "beyond the Anglo-America." True, researchers from other regions such as the Mediterranean and Latin America have also begun establishing geographies of sexualities, and they have at least partially succeeded in piercing into the mainstream geography especially in the context of feminist geography (Cortés et al., 2007; Ferreira and Salvador, 2014; Johnston and Longhurst, 2009; Sibalis, 2004; Silva and Vieira, 2014), yet it is safe to say that sexuality research has remained silenced, and largely "Western-oriented," both methodologically, theoretically and discursively.

To date, only scant attention has focused on Central and Eastern European geographies of sexualities, while the authors have repeatedly warned us about the potential risks connected with the uncritical repro- or introduction of foreign discourses (Kuhar and Švab, 2014; Kulpa, 2014; Kulpa and Mizieliñska, 2011; Navickaite, 2014; Stella, 2013). Although authors from outside the "West" have already begun uncovering various geographies of gender and sexualities within this particularly diverse region, these have often not been labeled as feminist geographies or geographies of sexualities. Rather they started to appear as part of diverse traditions built upon quite different academic cultures, often constraining them by lacking supportive structures and by presence of rigid disciplinary traditions (Timár, 2007).

One of the most significant differences that influence the development of feminist geographies and geographies of sexualities in CEE are substantially different discursive and related epistemic power-geometries within local and regional "geographical schools" (Massey, 1993). First, it is necessary to acknowledge that geography as a discipline within many of the CEE national and regional context represents a very distinct field with specific forms of local epistemic hegemonies, including publication traditions functioning as obstacles.

Nonetheless, it may be easy for a student to spend a semester abroad and become informed in some extra-departmental discourse in an increasingly interconnected, globalized and well-networked world. And while this may encourage or nourish the student's desire to focus on these fields, what may be much harder is to retain this focus and defend this desire following one's arrival back into the well-established department. In association with the first part of this article on various hegemonic influences, it is then the various positionalities of concrete researchers; the relation between their desires and respective subject matters; their attitudes toward academic mobility; their willingness to become scholarly nomads and/or to leave their partners, parents, friends or families behind; the language skills; the competitive and managerial climate (pressure to publish, pressure to obtain independent funding, presence of sup- 
port) and other factors that influence various local academic traditions, their forms and speeds at which different subfields, including the development of feminist and sexuality/queer though in human geography, that all influence establishment of these fields by given scholars.

Local cultural, political, and language traditions shape the forms and career paths of scholars. These are as well shaped by privileged individuals who act as gatekeepers of proper geographical knowledges. These individuals, regardless of the state of international discussions and discourses within the key geographical journals (even if most occur in English), exercise their local influence and defy these developments imbued with their subjective, political or other beliefs. Consequently, they decide what is being taught at their departments and by whom. They might disregard theories or approaches they deem "soft" and disempower scholars from contributing to the international debates by, for example, selecting new employees who are more "compliant" with their prevailing "mainstream understandings of what geography constitutes" and what or who should remain excluded. Therefore, even if geographers receive proper education at renowned universities, they still must "establish themselves" within certain intersubjective departments, where it is the discursive situatedness located at certain coordinates within concrete philosophical power-geometries that decide whether they can stay or not regardless of their desire or diligence. Many geography scholars from $\mathrm{CEE}$ and beyond could certainly name the specific local discursive resistances which they have to (or had to) face. Within these hegemonies, feminist geographies and even more so geographies of sexualities may be othered and resisted as "not enough geographical," too "interdisciplinary," "peripheral" or "out of place" (Pitoňák and Klingorová, 2019). They may be categorized as "soft," put together with other disregarded categories of difference such as gender, race or (dis)ability. They may continue to be depreciated based on the preference of "hard" quantitative and positivist methods, thus devaluing qualitative methods and theoretical research due, for example, to a dominant focus on regional and applied approaches.

It is no coincidence then why Timár and Fekete (2010) speak of a "fight for recognition" when they discuss feminist geography in CEE. According to the authors, even after nearly 30 years has passed since the fall of communism, mainstream geographical perspectives in CEE remain largely gender- and even human-blind, thus almost entirely blind towards sexualities. They further specify that it is the alleged objectivity and neutrality of social(ist) geography that prevailed within the mainstream and prevented geography from focusing on social/human problems (ibid. 2010: 778). Voiculescu (2011) supports this explanation from a Romanian perspective, where she argues that the socialist geography focused only on "the economic geography that had practical relevance for the communist system. As though in the universities, it was highly quantitative and descriptive, not connected to the diverse spheres of everyday life" (Voiculescu, 2011: 190). Although she explains that she and her colleagues were successful in establishing a gender and geography course 
at University of Timişoara already in 2004, they still face barriers and lack of recognition today.

Similarly, as (Blažek and Rochovská, 2006: 7) stated in their timely, brave and/or almost avant-garde book contribution to both Slovak and Czech $^{7}$ "feminist geographic thought", although "Western" human geographical has found a way to accept feminist theory, Slovak academia gave space only to isolated groups of feminist scholars, whereas "geography, perhaps also due to its interdisciplinarity and lack of unity, has been so far immune to its onset" disregarding it within the field of geography almost entirely. And this "power-geometrical immune system" has seemed to last, although authors have recognized that the development of feminist thought is actively resisted. One of the symptoms of this resistance is the fact that these approaches are still considered to be relatively new, even three decades after the fall of communism (Pitoňák, 2014; Pospíšilová and Pospíšilová, 2014; Timár and Fekete, 2010). Therefore, even if feminist geography was not academically pursued within CEE up until the dismantling of socialism (Timár, 2007), the following transitional years enabled it only minimal (peripheral) attention and visibility. In their recent effort to (re)introduce feminist thought into Czech geography, Pospíśilová and Pospíśilová (2014: 118) summed up that geographical departments in Czechia almost entirely omit feminist geographies, which is reflected by a low number of completed theses defended in this field, The situation in the Czech context is also well reflected by Daněk (2013), who admitted that feminist geographical thought has been presented at numerous occasions and they themselves contribute to summarizing the leading works of, mostly foreign, scholars in the field. However, he also concluded that for many geographers the word feminism still conveys a negative or pejorative content and they remain reserved to the idea of connecting feminism with geography. He closed that critical perspectives such as knowledge situatedness are considered abstract theories by several geographers who "do not have the capacity to shake them in their conviction about rightfulness of their search for universal objective explanation" (Daněk, 2013: 104).

Timár and Fekete (2010: 783) corroborated this from a Hungarian perspective when they wrote that: "there are acclaimed professors (in Hungary and Slovakia for example) who are in open denial of the very existence of feminist geography and expressly discourage their students from studying it." Inclusion of feminist and other social-critical approaches (including sexuality and queer approaches) within the context of CEE thus truly resembles a "fight" with the conservative, empiricist and still largely positivist local mainstream geographical traditions which are recognized as main obstacles in the development of this field (Pitoňák and Klingorová, 2019; Timár and

7. Due to mutual closeness of our two countries, almost entire language understandability, shared history and culture both academic cultures continue to mutually influence each other. 
Fekete, 2010). If it is still considered "brave" to pursue gender and feminist theories, then pursuing research in the field of geographies of sexualities and queer theories within local geographies may be simply unpalatable by many local departments. Those who are willing to counter mainstream geography and apply "locally novel" theoretical and methodological approaches are often deemed as "dissident geographers." They/we have to negotiate with both the local "arbiters of human geographical thought", and the various hegemonies posing as obstacles in their access to knowledge and ability to participate as knowledge producers themselves. Although I called for scrutinizing the Anglo-American hegemonic knowledges, I should also caution about the typical disregard and lack of comprehension that is often manifested in the broad indifference for "post-modern", "feminist" or other thought viewed as "foreign" by some of these arbiters. In this sense, the local arbiters of geographical thought who, in the context of neoliberal academia, "are worried that the position of geography will be eroded by the adoption of 'foreign' approaches and methods, including those applied in interdisciplinary gender studies, and through further specialisation" (Timár and Fekete, 2010: 778) may perpetuate divisions and boundaries between knowledge exchange and collaborations, based solely on their professed roles in defending the "disciplinarity" of geography against the wider influences of "interdisciplinarity" (Pitoňák and Klingorová, 2019). Consequently, many with non-confrontational personalities may instead succumb to "local pressures" and/or vacate the field rather than "stay in dissent."

This is also one of the reasons why local scholarly boundaries within CEE largely remained bound by the national boundaries (Bajerski and Siwek, 2012), thus leaving them somewhat perplexingly disconnected and fueled by specific regional methodological nationalisms (Navickaite, 2014) that uncritically promote approaches or theories which exercise local influence, but lack international recognition and/or corrective reflecting. This is then well evidenced in a high degree of intra-national and intra-departmental publication/citation traditions (Bajerski and Siwek, 2012). Thus, even if numerous critics have repeatedly voiced themselves and presented their contributions at local, regional and international conferences, they/we have so far been unable to establish themselves/ourselves within their/our local geographical mainstreams.

To introduce the feminist and other critical approaches into CEE geographies, authors have for example criticized the insufficient methodological and theoretical prowess of geographers, and called for the introduction of feminist-meaning qualitative-methods (Matoušek, 2013; Rochovská et al., 2007). However as these methods have often borrowed from Anglo-American feminist geography, interdisciplinary gender studies or critical theory, it has been the introduction of these "approaches, practices and methods, modern or even post-modern by 'East-Central European standards', that generate[d] the strongest resistance from traditional geography" (Timár and Fekete, 2010: 782). 
Timár and Fekete (2010: 779) put it aptly when they argued that: "Strangely enough, it was through working in east-west co-operation or networking that we, representatives of feminist geography in various countries in ECE, 'stumbled upon one another". In the context of lacking support, opportunities, and recognition, it is then no surprise that cooperation outside of the region is more plausible then networking within it.

The project of establishing feminist/gender geographies as well as geographies of sexualities in CEE only starts by recognizing the main foci of opposition. By understanding various power-knowledge and hegemonic relations, we need to be conscientious of ways we may further be delayed in the success of our efforts; for example, by navigating the demands of publishing internationally. Timár and Fekete put it eloquently:

We must plan a scheme to fight the views that are in denial of the very justification of feminist geography and refuse to recognize it as geography. Geographers will have to fight this battle primarily against mainstream geography in the country where they live. For the time being, challengers are not among the readers of Gender, Place and Culture and other similar journals, no matter how much we would like things to be otherwise; therefore, publishing abroad cannot replace publishing locally. (2010: 784)

Even if we find some balance between publishing in our local languages and using English or another language to share our ideas with colleagues across national boundaries, we will still need to face barriers in access to scientific literature, insecure job situation, lack of funding opportunities or academic infrastructure that restrict us from contributing/cooperating in this "fight for recognition" (Kulpa and Silva, 2016). The discussed epistemic power-geometries will continue to influence the success rates of our grant applications, the existing research teams will regulate who will be accepted and who will be hired, who will be the "researcher," and who will be the "data miner."

\section{Conclusion}

Whether we focus on countering the hegemonic influences of Anglo-American thought or empowerment of dissident geographers of sexualities or feminist geographers attempting to establish themselves within the context of CEE, I believe it is crucial to remember that all these relations still refer to relations between human actors, researchers, scholars, and others. ${ }^{8}$ I want to close this article by showing an example of success from abroad, and although there might be numerous other positive experiences, ${ }^{9}$ I decided to quote an example regarding the creation of The Group on Gender Studies in Geography at the Autonomous University of Barce-

8. Although at some point in the near future, A.I. and other less sophisticated actors such as automated translation services will increasingly influence them as well.

9. For example, French geographies of sexualities and feminist geographies (Creton, 2007) or the experience of German and Austrian feminist geography (BASSDA, 2006). 
lona. This group was founded in 1987 and formally recognized by the administration of the university in 1995. I consider the following as particularly inspiring:

From its initiation, this Group was directed by Maria Dolors Garcia Ramon, an established full professor. This situation contrasts with that in some other countries where those attempting to introduce gender research and teaching are junior scholars. The Barcelona group consciously adopted strategies that would advance and consolidate its position. These included: incorporating multiple members of the department, including young researchers and graduate students; seeking external research funds (regional, national and international); developing competitive scholarly records by publishing in refereed journals, nationally and internationally; teaching specialised courses in gender; establishing a modest documentation centre on themes related to its research; presenting at international meetings; forming a supportive local informal network; and establishing relations with geographers outside Spain, by going abroad themselves and inviting foreign geographers into the department. (Cortés et al., 2007: 3)

\section{Bibliographical references}

Awumbila, Mariama (2007). "Challenging contexts: Gender studies and geography in Anglophone African countries”. Revue Belge de Géographie, 3, 0-16. <https://doi.org/10.4000/belgeo.11172>

Ayoub, Phillip and PaternotTe, David (eds.). (2014). LGBT Activism and the Making of Europe. London: Palgrave Macmillan UK. <https://doi.org/10.1057/9781137391766>

BAJERSKI, Artur and SiWEK, Tadeusz (2012). "Bibliometrická analýza české geografie v databázi Scopus.” Geografie, 117 (1), 52-71.

Balogh, Péter (2017). "The revival of 'Central Europe' among Hungarian political elites: its meaning and geopolitical implications". Hungarian Geographical Bulletin, 66 (3), 191-202. <https://doi.org/10.15201/hungeobull.66.3.1>

BASSDA (2006). "A Kind of Queer Geography/Räume Durchqueeren: The Doreen Massey Reading Weekends”. Gender, Place \& Culture, 13 (2), 173-186. <https://doi.org/10.1080/09663690600573841>

BASSNETT, Susan (1992). "Crossing cultural boundaries: Or how I became an expert on east European women overnight”. Women's Studies International Forum, 15 (1), 11-15. <https://doi.org/10.1016/0277-5395(92)90028-T>

Bell, David and Valentine, Gill (1995). Mapping Desire: Geographies of Sexualities. London: Routledge.

BenhabIB, Seyla (2011). Dignity in Adversity: Human Rights in Troubled Times. Malden, MA and Cambridge, UK: Polity.

Berger, Peter and Luckmann, Thomas (1991). The social construction of reality: A treatise in the sociology of knowledge. London: Penguin.

BINNIE, Jon (1995). "Trading places: consumption, sexuality and the production of queer space". In: Bell, David and Valentine, Gill (eds.). Mapping Desire: Geographies of Sexualities. London, UK: Routledge, 182-199.

BlAŽEK, Matej and RochovskÁ, Alena (2006). Feministické geografie. Bratislava: Geografika. 
BLAŽEK, Matej and ŠUŠKA, Pavel (2017). “Towards dialogic post-socialism: Relational geographies of Europe and the notion of community in urban activism in Bratislava”. Political Geography, 61, 46-56.

<https://doi.org/10.1016/j.polgeo.2017.06.007>

Brown, Gavin and Browne, Kath (eds.). (2016). The Routledge Research Companion to Geographies of Sex and Sexualities. London and NY: Routledge.

Browne, Kath; Lim, Jason and Brown, Gavin (eds.). (2007). Geographies of Sexualities Theory, Practices and Politics. Aldershot: Ashgate.

Browne, Kath and NASH, Catherine. J. (2017). "Heteroactivism: Beyond Anti-Gay". ACME: An International Journal for Critical Geographies, 16 (4), 643-652.

ButLer, Judith (1999). Gender trouble. Oxon: Routledge. Retrieved from <http:// www.google.com/books?hl=cs\&lr=\&id=_mSTAgAAQBAJ\&oi=fnd\&pg=PP1\& $\mathrm{dq}=$ butler + judith + gender + trouble\&ots=TXD2T0SpUT\&sig=Jmz8PzEEAz5BIs YJ1g4oKF57axc>

Cortés, Fabia Diaz; Garcia Ramon, Maria Dolors and Ortiz, Anna (2007). "Engendering Spanish geography". Revue Belge de Géographie, 3, 0-12. $<$ https://doi.org/10.4000/belgeo.11207>

Creton, Dominique (2007). "Gender issues in French geography”. Revue Belge de Géographie, 3, 0-12. <https://doi.org/10.4000/belgeo.11201>

DANĚK, Petr (2013). Geografické myšleni: úvod do teoretických př́stupio. Brno: Masarykova univerzita. <https://doi.org/10.5817/CZ.MUNI.M210-6694-2013>

EBERLE, Jakub (2018). "Desire as Geopolitics: Reading The Glass Room as Central European Fantasy". International Political Sociology, 12 (2), 172-189. <https://doi.org/10.1093/ips/oly002>

FERREIRA, Eduarda and SALVADOR, Regina (2014). "Lesbian collaborative web mapping: disrupting heteronormativity in Portugal”. Gender, Place \& Culture, 22 (7), 954-970. <https://doi.org/10.1080/0966369X.2014.917276>

Garcia Ramon, Maria Dolors and Monk, Janice (2007). "Gender and geography: World views and practices". Revue Belge de Géographie, 3, 0-14. <https://doi.org/10.4000/belgeo.11162>

Garcia Ramon, Maria Dolors; Simonsen, Kirsten and Vaiou, Dina (2006). "Guest Editorial: Does Anglophone hegemony permeate Gender, Place and Culture?”. Gender, Place \& Culture, 13 (1), 1-5. <https://doi.org/10.1080/09663690500530867>

Johnston, Lynda and Longhurst, Robin (2009). Space, Place, and Sex: Geographies of Sexualities. Plymouth: Rowman \& Littlefield.

KitCHIn, Rob (2003). "Cuestionando y desestabilizando la hegemonía angloamericana y del inglés en geografía”. Documents d'Anàlisi Geogràfica, 43, 17-36.

- (2005). "Commentary: Disrupting and destabilizing Anglo-American and Englishlanguage hegemony in geography”. Social \& Cultural Geography, 6 (1), 1-15. <https://doi.org/10.1080/1464936052000335937>

KolÁŘOVÁ, Kateřina (2013). "Homosexuální asociál a jeho zavirované tělo". In: HiML, Pavel; SEIDL, Jan and SCHIndLER, Franz (eds.) (2013). "Miluji tvory svého pohlaví": homosexualita v dějinách a společnosti českých zemí. Praha: Argo, 411-452.

KuHAR, Roman and ŠvaB, Alenka (2014). "The Only Gay in the Village? Everyday Life of Gays and Lesbians in Rural Slovenia”. Journal of Homosexuality, 61 (8), 1091-1116. <https://doi.org/10.1080/00918369.2014.872492> 
KuLPA, Robert (2014). "Western leveraged pedagogy of Central and Eastern Europe: discourses of homophobia, tolerance, and nationhood". Gender, Place \& Culture, 21 (4), 431-448. <https://doi.org/10.1080/0966369X.2013.793656>

KulPA, Robert and MizieliñsKA, Joanna (eds.). (2011). De-Centring Western Sexualities Central and Eastern European Perspectives. Burlington: Ashgate.

KulPA, Robert and Silva, Joseli Maria (2016). "Decolonizing Queer Epistemologies: Section Introduction”. In: Brown, Gavin and Browne, Kath (eds.). The Routledge Research Companion to Geographies of Sex and Sexualities. Oxon: Routledge, 139-143.

Kundera, Milan (1984). "The Tragedy of Central Europe”. The New York Review, 33-38. Retrieved from <http://is.muni.cz/el/1423/podzim2013/SOC571E/um/ Kundera_TragedyofCentralEurope.pdf>

KurimaY, Anita and TAKÁCS, Judit (2017). "Emergence of the Hungarian homosexual movement in late refrigerator socialism". Sexualities, 20 (5-6), 585-603. https://doi.org/10.1177/1363460716665786>

MASSEY, Doreen (1993). "Power-geometry and a progressive sense of place". In: BIRD, Jon; Curtis, Barry; Putnam, Tim and Tickner, Lisa (eds.). Mapping the Futures: Local Cultures, Global Change. London: Routledge, 60-70.

MATOUŠEK, Roman (2013). "Jaké metody pro jakou geografii? K prŕínosu geografie a inspiraci z jiných disciplín”. Informace Ć $G S, 32$ (1), 16-24.

MCKAY, Richard. A. (2014). "'Patient Zero': The Absence of a Patient's View of the Early North American AIDS Epidemic". Bulletin of the History of Medicine, 88 (1), 161-194. <https://doi.org/10.1353/bhm.2014.0005>

NAVICKAITE, Rasa (2014). "Postcolonial queer critique in post-communist Europe Stuck in the Western progress narrative?". Tijdschrift Voor Genderstudies, 17 (2), $165-185$. <https://doi.org/10.5117/TVGEND2014.2.NAVI>

Pachankis, John E.; Hatzenbuehler, Mark L.; Mirandola, Massimo; WeatherBurn, Peter; Berg, Rigmor C.; Marcus, Ulrich; and Schmidt, Axel J. (2016). "The Geography of Sexual Orientation: Structural Stigma and Sexual Attraction, Behavior, and Identity Among Men Who Have Sex with Men Across 38 European Countries". Archives of Sexual Behavior, 46 (5), 1491-1502. <https://doi.org/10.1007/s10508-016-0819-y>

PitoňÁK, Michal (2014). "Prostorovost města v kontextu (homo/hetero)sexuality: úvod do teoretické diskuse". GEOGRAFIE, 119 (2), 179-198.

PitoňÁK, Michal and KLINGOROVÁ, Kamila (2019). "Development of Czech feminist and queer geographies: identifying barriers, seeking progress”. Gender, Place \& Culture. <https://doi.org/10.1080/0966369X.2018.1563528>

PITOŇÁK, Michal and SPILKOVÁ, Jana (2016). Homophobic Prejudice in Czech Youth: a Sociodemographic Analysis of Young People's Opinions on Homosexuality. Sexuality Research and Social Policy, 13 (3), 215-229. <https://doi.org/10.1007/s13178-015-0215-8>

PospíšilovÁ, LuCIE and PospíšilovÁ, Klára (2014). "Feministické prostory". In: Matoušek, R. and Osman, R. (eds.). Prostor(y) Geografie. Praha: Karolinum, 99-122.

Rochovská, Alena; BlažEK, Matej and SoKOL, Martin (2007). "Ako zlepšit kvalitu geografie: O dôležitosti kvalitatívného výskumu v humánnej geografii”. Geografický Casopis, 59 (1), 323-358. 
Rodó DE ZÁRATE, Maria (2016). "Feminist and Queer Epistemologies beyond Academia and the Anglophone World: Political Intersectionality and Transfeminism in the Catalan Context". In: Brown, Gavin and Browne, Kath (eds.). The Routledge Research Companion to Geographies of Sex and Sexualities. London: Routledge, 155-164.

SEDGWICK, Eve Kosofsky (1990). Epistemology of the Closet. Berkeley: University of California Press.

Sibalis, Michael (2004). "Urban Space and Homosexuality: The Example of the Marais, Paris' 'Gay Ghetto'”. Urban Studies, 41 (9), 1739-1758.

<https://doi.org/10.1080/0042098042000243138>

Silva, Joseli Maria and VieIRA, Paulo Jorge (2014). "Geographies of Sexualities in Brazil: Between National Invisibility and Subordinate Inclusion in Postcolonial Networks of Knowledge Production”. Geography Compass, 8 (10), 767-777. <https://doi.org/10.1111/gec3.12165>

STELla, Francesca (2013). "Lesbian lives and real existing socialism in late Soviet Russia”. In: TAYLOR, Yvette and ADDISON, Michelle (eds.). Queer Presences and Absences. Basingstoke: Palgrave, 50-68.

- (2014). "Introduction: locating Russian sexualities". Lesbian Lives in Soviet and Post-Soviet Russia, 1-40.

- (2015). Lesbian Lives in Soviet and Post-Soviet Russia. London, UK: Palgrave Macmillan. <https://doi.org/10.1057/9781137321244>

Stella, Francesca; Flynn, Moya and GaWlewiCZ, Anna (2017). "Unpacking the Meanings of a 'Normal Life' Among Lesbian, Gay, Bisexual and Transgender Eastern European Migrants in Scotland". Central and Eastern European Migration Review, 7 (1), 55-72.

<https://doi.org/10.17467/ceemr.2017.16>

ŠTUlHOFER, Aleksandar and SANDFORT, Theo (eds.) (2005). Sexuality and gender in postcommunist Eastern Europe and Russia. Binghamton, NY: The Haworth Press.

SzULC, Lukasz (2018). Transnational Homosexuals in Communist Poland. Switzerland: Palgrave Macmillan. <https://doi.org/10.1007/978-3-319-58901-5>

TimÁR, Judit (2007). "Gender studies in the genderblind post-socialist geographies of East-Central Europe". Belgeo, 3, 349-369. $<$ https://doi.org/10.4000/belgeo.11217>

Timár, Judit and FeKeTE, Éva G. (2010). "Fighting for recognition: feminist geography in East-Central Europe”. Gender, Place \& Culture, 17 (6), 775-790. <https://doi.org/10.1080/0966369X.2010.517027>

Tlostanova, Madina (2014). "Why the Post-socialist Cannot Speak: on Caucasian Blacks, Imperial Difference and Decolonial Horizons". In: BroecK, Sabine and Junker, Carsten (eds.). Postcoloniality-Decoloniality-Black Critique. Joints and Fissures. Frankfurt and New York: Campus Verlag, 159-173.

VAlENTINE, Gilland and HARris, Catherine (2016). "Encounters and (in)tolerance: perceptions of legality and the regulation of space". Social \& Cultural Geography, 17 (7), 913-932. <https://doi.org/10.1080/14649365.2016.1139171>

VOICULESCU, Sorina (2011). "Teaching gender and geography in Romanian universities". International Research in Geographical and Environmental Education, 20 (3), 189-193. <https://doi.org/10.1080/10382046.2011.588497> 
